\title{
Voorlopige contouren van bestuursgericht toezicht
}

\section{Empirische inzichten in jonge praktijken van bestuursgericht toezicht ${ }^{*}$}

Thomas Schillemans, Meike Bokhorst, Marieke van Genugten \& Mirjan Oude Vrielink

De toezichthouders in onderwijs, zorg en wonen richten zich de laatste jaren steeds nadrukkelijker ook op het bestuur van instellingen. Bij de introductie van het vernieuwde toezicht eind 2016 stelde de Inspectie van het Onderwijs dat bestuursgericht toezicht 'beter zou aansluiten bij de verantwoordelijkheid' van besturen en scholen en dat de inzet was om daarmee de kwaliteit van onderwijs te stimuleren (Inspectie van het Onderwijs, 2016). De Inspectie Gezondheidszorg en Jeugd (2016) stelt op de eigen website dat er in het toezicht 'meer en meer aandacht' zou zijn voor de bestuurscultuur binnen instellingen. En voor de Autoriteit wonen staat de governance van corporaties centraal in het toezicht op individuele corporaties (Autoriteit woningcorporaties, 2018). Bestuursgericht toezicht is daarmee een duidelijke ambitie voor de toezichthouders, waar verschillende redenen voor zijn, die elders in dit themanummer worden besproken. De vraag in dit artikel is echter: wat merken instellingen daar nu in de praktijk al van; en wat voor directe, maar ook indirecte effecten lijkt deze wending naar bestuursgericht toezicht te hebben?

Om deze vragen te beantwoorden doen we in dit artikel verslag van de resultaten van een beperkte survey die medio 2018 is uitgevoerd onder bestuurders en vooral interne toezichthouders bij woningcorporaties, onderwijs- en zorginstellingen. Het was een beperkte vragenlijst met 124 respondenten, van wie $61 \%$ de vragenlijst volledig invulde. Het zijn, zoals de titel al suggereert, 'voorzichtige contouren'; eerste indrukken die nadrukkelijk niet als conclusies, maar als voorlopige contouren en als hypothesen voor nadere reflectie en onderzoek dienen te worden gelezen. Doel van het artikel is vooral om de empirische basis van dit themanummer te versterken en de jonge praktijk van bestuursgericht toezicht vanuit het perspectief van interne toezichthouders en bestuurders bij instellingen te verkennen.

* Prof. dr. T. Schillemans is hoogleraar Bestuurskunde (verantwoording, gedrag en instituties) aan de Universiteit Utrecht.

Dr. M. Bokhorst is senior wetenschappelijk medewerker bij de Wetenschappelijke Raad voor het Regeringsbeleid en onderzoeker aan de Universiteit Utrecht (a.m.bokhorst@uu.nl). Dr. M. van Genugten is universitair docent bestuurskunde aan de Radboud Universiteit. Dr. M. Oude Vrielink is onderzoeker bij Oude Vrielink Dienstverlening-Partner in kennis.

Dit artikel is onderdeel van het NWO Vidi-project 'Calibrating Public Accountability', zie https:// accountablegovernance.sites.uu.nl. Dank gaat uit naar Maj Grove Jeppesen voor onderzoeksassistentie. 


\section{De survey}

De survey is in het voorjaar van 2018 uitgevoerd. De vragenlijst bestond uit drie componenten. In de eerste plaats waren er vragen die specifiek gingen over ervaringen met en de inhoudelijke focus van het (al dan niet) bestuursgerichte toezicht. In de tweede plaats waren er vragen over de rol van de respondent en de organisatie. In de derde plaats zijn vragen gebruikt uit een groter internationaal onderzoek naar toezicht en verantwoording, waarmee de mogelijke impact van bestuursgericht toezicht ook theoretisch nader kan worden begrepen en geanalyseerd.

De survey is via nieuwsbrieven en mailings vanuit professionele organisaties gedistribueerd binnen bestaande netwerken van interne toezichthouders en bestuurders van instellingen in onderwijs, zorg en wonen. ${ }^{1}$ Dit heeft als voordeel dat we direct toegang hadden tot bestaande netwerken binnen de doelgroep, maar betekent ook dat we geen controle hadden over de doelgroep en de representativiteit van de sample. In totaal hebben 124 respondenten de vragenlijst beantwoord, van wie 75 volledig (61\%), tussen 24 mei en 30 juni 2018. De survey is uiteindelijk door veel meer interne toezichthouders (81\%) ingevuld dan door bestuurders; de indrukken waar we in dit artikel over rapporteren, zijn daarmee in belangrijke mate vooral de beelden van het externe toezicht door de ogen van interne toezichthouders. Wel meende $90 \%$ van de respondenten dat ze de vragenlijst konden beantwoorden omdat ze in hun rol bijna altijd zicht hebben op de relatie met de externe toezichthouder'. De onderwijssector is verder oververtegenwoordigd in de antwoorden. 50\% van de respondenten gaf aan actief te zijn in onderwijs, $28 \%$ in de zorg en $15 \%$ bij woningcorporaties. Vanwege de kleine $\mathrm{N}$ van het onderzoek en de verschillen tussen de sectoren, rapporteren we in dit artikel alleen op geaggregeerd niveau. Bij de meeste organisaties was de externe toezichthouder in het afgelopen jaar op bezoek gekomen (88\%) of anders wel in het jaar daarvoor (10\%). Gelet op de invoering van het vernieuwde toezicht in het onderwijs alsook de ontwikkelingen in zorg en wonen, betekent dit dat de respondenten op zijn minst eerste ervaringen met bestuursgericht toezicht kunnen hebben gehad. Welke beelden komen daar nu uit naar voren?

\section{Relatie met de toezichthouder}

We beginnen eerst algemeen bij de (verantwoordings)relatie tussen de instelling en de externe toezichthouder. Om die te onderzoeken maken we gebruik van Bovens' driefasemodel van verantwoording, dat onderscheid maakt tussen het verstrekken van informatie over het instellingshandelen aan - in dit geval - de toezichthouder (informatiefase), de bespreking daarvan (debatfase) en vervolgens

1 Uitnodiging tot deelname aan het onderzoek is verzonden via de nieuwsbrieven van het netwerk The Midfield (www.themidfield.nl) en de verenigingen van interne toezichthouders in de zorg (NVTZ, www.nvtz.nl) en het onderwijs (VTOI-NVTK, www.vtoi-nvtk.nl). Onze dank gaat uit naar deze netwerken en onze contactpersonen, en uiteraard naar de respondenten die de survey hebben ingevuld. 
Tabel 1 Frequenties informatievoorziening aan externe toezichthouder*

\begin{tabular}{lll}
\hline & Gemiddelde & SD \\
\hline Periodieke rapportage & $3,5 \mathrm{I}$ & $\mathrm{I}, 25$ \\
Memo of brief & 3,46 & $\mathrm{I}, 19$ \\
Informele kanalen & 3,28 & $\mathrm{I}, 49$ \\
Overige kanalen & 2,69 & $\mathrm{I}, 38$ \\
Instellingsaudit of vergelijkbaar & 2,60 & $\mathrm{I}, 0 \mathrm{I}$ \\
Zelfevaluatie & 2,17 & $\mathrm{I}, 07$ \\
\hline
\end{tabular}

* Bij deze vraag staat ' 2 ' voor een frequentie van minder dan één keer per jaar, ' 3 ' voor jaarlijks en ' 4 ' voor 2-5 keer per jaar.

de mogelijke consequenties (sanctioneringsfase) (Bovens \& Schillemans, 2009). Hiermee ontstaat een eerste beeld van de toezichts- en verantwoordingsrelaties tussen externe toezichthouders en instellingen.

Onze respondenten geven aan dat hun instellingen via verschillende kanalen rapporteren aan hun externe toezichthouder. Tabel 1 geeft een overzicht dat in aflopende frequentie van informatievoorziening is geordend. Als we tabel 1 interpreteren, dan suggereert dit dat de instellingen gemiddeld ongeveer drie à vier rapportages en memo's of brieven per jaar opstellen voor de externe toezichthouder, er daarnaast iets minder informele informatieoverdracht is, en tot slot er minder dan jaarlijkse informatieoverdracht langs andere kanalen plaatsvindt. Of dit veel of weinig is, is moeilijk te zeggen. De informatiefrequentie is in ieder geval duidelijk lager dan is gerapporteerd door agentschappen en 'zelfstandige bestuursorganen (Overman et al., 2018). Dat lijkt ook niet meer dan logisch, omdat scholen, zorginstellingen en woningcorporaties overwegend privaatrechtelijke stichtingen zijn, die op grotere afstand van overheidstoezichthouders staan dan agentschappen en zbo's. Opvallend is verder dat de frequentie van informeel contact sterk varieert. Sommige respondenten rapporteren veel informele informatie-uitwisseling, terwijl andere aangeven dat juist weinig te doen. Dit onderscheid tussen formele en informele interacties lijkt betekenisvol te zijn en komt ook op andere plaatsen in ons onderzoek naar voren, zo zullen we later bespreken.

Op dezelfde wijze is vervolgens gevraagd hoe vaak de instelling contact heeft met de toezichthouder ('debatfase') in de zin van formele of informele gesprekken op het hoogste bestuurlijke niveau en ook lager in de organisatie. Samengevat komt het erop neer dat ze gemiddeld ongeveer een- à tweemaal per jaar contact hebben. De respondenten rapporteren hier iets meer informele dan formele contacten, al is het verschil niet heel groot. Opnieuw liggen de frequenties (en opnieuw begrijpelijkerwijs) een stuk lager dan bij agentschappen en zbo's in het eerdere onderzoek met dezelfde vragen. En opnieuw is de variëteit rond informeel contact tussen onze respondenten vrij hoog; er lijken vooral ofwel overwegend formele, ofwel juist sterk informele contactpatronen met de externe toezichthouder te bestaan. 
Tabel 2 Bestaan en waarschijnlijkheid van toepassing van sancties*

\begin{tabular}{lll}
\hline & Gemiddelde & SD \\
\hline Negatief oordelen & 2,07 &, 87 \\
Vervolgtoezicht instellen & 2,16 &, 77 \\
Negatief rapporteren & 2,24 &, 86 \\
Bijzondere richtlijnen afgeven & 2,43 &, 77 \\
Bestuurlijke boete & 3,06 &, 83 \\
Beïnloeden carrièremogelijkheden bestuurder & 3,33 &, 85
\end{tabular}

* In deze tabel geeft ' 2 ' aan dat het enigszins waarschijnlijk is dat een bepaalde sanctie wordt ingezet, terwijl ' 3 ' aangeeft dat het onwaarschijnlijk is en ' 4 ' dat het niet mogelijk is.

Vervolgens is gevraagd naar het bestaan van verschillende soorten mogelijke sancties en naar de waarschijnlijkheid dat de externe toezichthouder die ook daadwerkelijk inzet. Sancties worden in de literatuur vaak geïnterpreteerd als een ladder die start bij lichte en informele interventies en kan - of zou moeten - escaleren richting zwaardere en geformaliseerde sancties (Ayres \& Braithwaite, 1995; Hood, James, Scott, Jones, \& Travers, 1999, p. 47). Dit is ook goed zichtbaar in de antwoorden van onze respondenten, samengevat in tabel 2. De tabel laat zien dat toepassing van de meest informele sanctie van negatief oordelen het meest waarschijnlijk wordt geacht, terwijl respondenten toepassing van de zwaardere sancties juist minder waarschijnlijk vinden. Opnieuw is er de meeste variëteit rondom de informele optie van een negatief oordeel, zoals er ook de meeste variëteit in antwoorden was rond informele informatie-uitwisseling en informele contacten. Overkoepelend laat het zien dat de externe toezichthouder over verschillende sanctioneringsmogelijkheden beschikt, die echter, zoals wel vaker gerapporteerd, met terughoudendheid worden benut.

\section{Bestuursfocus?}

De respondenten die aan ons onderzoek hebben deelgenomen, geven in overgrote meerderheid (90\%) aan vanuit hun functie goed zicht te hebben op de relatie met de externe toezichthouder. Ze zijn meestal al langer aan de organisatie verbonden (gemiddeld ongeveer vijf jaar) en hun instellingen zijn bijna altijd recent bezocht door de toezichthouder. Herkennen zij in de praktijk nu die grotere focus op bestuur bij de externe toezichthouder?

Het antwoord op die vraag is in de kortst mogelijke samenvatting: soms wel en soms niet, soms in geringe mate en soms in sterke mate. Aan het einde van de vragenlijst gaven de respondenten aan de wending naar een grotere focus op het bestuur gemiddeld genomen enigszins (gemiddeld 3,44, waar 4 neutraal is) te herkennen. Dit gemiddelde antwoord is de resultante van sterk uiteenlopende antwoorden. Alle antwoordopties (tussen 1 en 7) zijn gebruikt door de respondenten. Er is een vrij grote spreiding en dus zijn er zowel sterk bevestigende alsook sterk 
ontkennende antwoorden. Sommige respondenten menen dat de focus op het bestuur inmiddels het belangrijkste punt is voor hun externe toezichthouder, terwijl andere menen dat dit juist helemaal niet relevant is.

Deze sterk verdeelde ervaring is ook zichtbaar in de open antwoorden die respondenten op dit punt geven. Aan de ene kant staan respondenten die menen dat er 'veel meer aandacht voor governance' is en dat zij binnen de organisatie worden 'aangesproken' op de 'bestuurlijke eindverantwoordelijkheid'. Aan de andere kant zijn er ook respondenten die menen dat het 'nog erg zoeken en wennen bij de inspectie' is, dat de 'roluitvoering onvoorspelbaar' is, en dat er 'geen effect' is. Om de bestuursgerichtheid van het toezicht verder te verkennen is respondenten gevraagd aan te geven in welke mate de toezichthouder aandacht besteedt aan een groot aantal bestuurlijke zaken. Deze nadere focus op bestuursgericht toezicht bevestigt het meer algemene beeld tot nu toe: veel gemiddelden tenderen naar het midden, maar dit wordt veroorzaakt door de vrij grote spreiding in de gegeven antwoorden op het spectrum tussen zeer sterke bevestiging en zeer sterke ontkenning. Het suggereert dat de respondenten het er niet met elkaar over eens zijn of de focus op bestuur nu wel of niet een merkbaar gegeven is in het toezicht op onderwijs, zorg en wonen. Dat is ook vaak kenmerkend voor nieuwe ontwikkelingen, dat ze op sommige plekken al wel en op andere plekken nog niet doordringen. En het is ook goed voorstelbaar dat de uitvoering van een beleidsintentie sterk varieert tussen verschillende personen en onderdelen van de organisatie.

Tabel 3 geeft een overzicht van de besproken bestuurlijke thema's in aflopende mate van frequentie.

\section{Tabel 3 Inhoudelijke foci bestuursgericht toezicht*}

\begin{tabular}{|c|c|c|c|}
\hline & & Gemiddelde & SD \\
\hline \multirow{3}{*}{$\begin{array}{l}\text { Gemiddeld overwegend herken- } \\
\text { baar voor respondenten in het } \\
\text { externe toezicht }\end{array}$} & Kwaliteitssystemen en -zorg & 5,49 & 1,67 \\
\hline & Instellingsaudit & 4,81 & 1,79 \\
\hline & Zelfevaluatie, visitatie e.d. & 4,76 & $\mathrm{I}, 88$ \\
\hline \multirow[t]{4}{*}{$\begin{array}{l}\text { Gemiddeld neutraal voor res- } \\
\text { pondenten }\end{array}$} & $\begin{array}{l}\text { Bestuurlijke organisatie en } \\
\text { governance }\end{array}$ & 4,29 & 2,23 \\
\hline & Checks-and-balances & 4,16 & 1,90 \\
\hline & Financiële continuïteit & 4,12 & 2,02 \\
\hline & Bestuurlijk vermogen & 4,07 & 2,02 \\
\hline \multirow{7}{*}{$\begin{array}{l}\text { Gemiddeld niet zo herkenbaar } \\
\text { voor respondenten in het } \\
\text { externe toezicht }\end{array}$} & Integriteitseisen & 3,23 & 2,19 \\
\hline & 'Fit and proper'-test & 3,00 & 2,57 \\
\hline & Stakeholdermanagement & 2,97 & 1,68 \\
\hline & Meldplicht RvT & 2,66 & 1,68 \\
\hline & Werving \& selectie & 2,28 & 1,99 \\
\hline & $\begin{array}{l}\text { Samenstelling en groepsdyna- } \\
\text { miek boardroom }\end{array}$ & 2,21 & 1,59 \\
\hline & Ontslagbevoegdheden & I,97 & 1,46 \\
\hline
\end{tabular}

* Schaal loopt van I tot 7, van 'in het geheel niet' tot 'in zeer sterke mate'. 
Figuur 1 Mogelijke doorwerking bestuursgericht toezicht

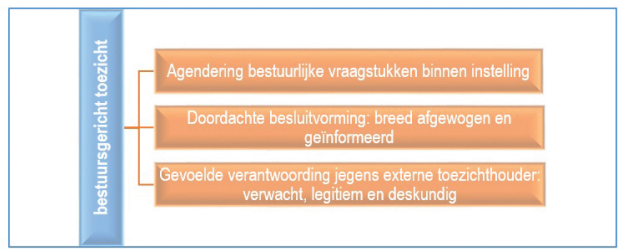

Tabel 3 geeft verder inzicht in de kennelijke prioriteiten en posterioriteiten in het bestuursgericht toezicht in de ervaring van onze respondenten. Evident komt uit de antwoorden naar voren dat kwaliteitssystemen en kwaliteitszorg voor hen de hoofdfocus in het bestuursgericht toezicht zijn. Het bestuursgericht toezicht lijkt zich daarmee hoofdzakelijk te richten op de systemen van kwaliteitszorg. Ook is er duidelijke aandacht voor 'grote meerjarendocumenten', zoals instellingsaudit, zelfevaluatie en visitatie. De meer specifieke aspecten die we hebben voorgelegd, en die vaak ook dicht op de rol van het bestuur komen, zoals werving en selectie, ontslagbevoegdheden en de dynamiek in de boardroom, vinden overkoepelend juist weer heel weinig herkenning. De voorzichtige conclusie die hieruit getrokken kan worden, is dat de bestuursfocus van het toezicht in de ervaring van de respondenten tamelijk systemisch is en gericht op de formele organisatie en de grote documenten met betrekking tot kwaliteitszorg. Aspecten van bestuurlijk vermogen en bestuurlijk gedrag komen volgens onze respondenten nauwelijks aan de orde.

\section{De doorwerking van bestuursgericht toezicht}

De mate van gerapporteerde bestuursgerichtheid van het toezicht wisselt al met al sterk tussen de respondenten. Dit roept de vraag op wat verschillen kan verklaren. Causaliteit is hier moeilijk vast te stellen, maar we kunnen wel kijken naar verbanden, waarbij we in het midden laten wat oorzaken of gevolgen zijn.

We nemen aan dat bestuursgericht toezicht op (minimaal) drie manieren door zou kunnen werken in het bestuur van instellingen. In de eerste plaats kan er een agenderend effect zijn: als de externe toezichthouder zich richt op bepaalde bestuurlijke thema's, kunnen die vervolgens ook belangrijker worden binnen de instellingen zelf. In de tweede plaats kan het een meer generiek effect op de kwaliteit van afwegingen hebben, door bestuurders aan te zetten tot nog beter doordachte en geïnformeerde beslissingen. In de derde plaats kan het tot een gevoelde verantwoording voor bestuurlijke zaken jegens de externe toezichthouder leiden, die het ook aannemelijker maakt dat de instelling het toezicht legitiem en belangrijk acht. Figuur 1 geeft deze relaties kort weer; we bespreken daarna onze bevindingen. 
Tabel $4 \quad$ Vergelijking relevantie bestuurlijke thema's in toezicht en binnen instelling*

\begin{tabular}{lll}
\hline & $\begin{array}{l}\text { Relevantie in toe- } \\
\text { zicht }\end{array}$ & $\begin{array}{l}\text { Relevantie binnen } \\
\text { instelling }\end{array}$ \\
\hline Kwaliteitssystemen en -zorg & 5,49 & 6,12 \\
Instellingsaudit & 4,81 & 5,24 \\
Zelfevaluatie, visitatie e.d. & 4,76 & 5,74 \\
Bestuurlijke organisatie en governance & 4,29 & 6,22 \\
Checks-and-balances & 4,16 & 5,98 \\
Financiële continuïteit & 4,12 & 6,29 \\
Bestuurlijk vermogen & 4,07 & 6,27 \\
Integriteitseisen & 3,23 & 6,14 \\
'Fit and proper'-test & 3,00 & 4,28 \\
Stakeholdermanagement & 2,97 & 5,75 \\
Meldplicht RvT & 2,66 & 5,06 \\
Werving \& selectie & 2,28 & 5,98 \\
Samenstelling en groepsdynamiek boardroom & 2,21 & 5,90 \\
Ontslagbevoegdheden & 1,97 & 4,74 \\
\hline
\end{tabular}

* Schaal loopt van I tot 7 , van 'in het geheel niet' tot 'in zeer sterke mate'.

\section{Agendering?}

Allereerst hebben we gekeken hoe belangrijk de respondenten de thema's vinden waar het bestuursgericht toezicht zich op kan focussen. Tabel 4 vergelijkt de gemiddelde relevantie van die bestuurlijke thema's binnen de instellingen met de mate waarin die thema's volgens respondenten object van extern toezicht zijn. De tabel laat in één oogopslag zien dat de relevantie van al die bestuurlijke thema's binnen de organisatie als (veel) hoger wordt gezien dan in het ervaren toezicht, waarbij het hoogste gemiddelde op 6,29 ligt (bij een maximum van 7). De interne toezichthouders en bestuurders geven hiermee aan dat zij de thema's van het bestuursgericht toezicht inderdaad belangrijk tot zeer belangrijk vinden voor het instellingsbestuur. Dit wordt verder onderschreven door een redelijk deel van de antwoorden van de respondenten in de open vragen. Zij geven daar aan dat het bestuursgericht toezicht 'qua issue prima', 'nuttig' en 'positief' is. Volgens onze respondenten gaat het bestuursgericht toezicht daarmee in ieder geval over relevante bestuurlijke zaken.

Vervolgens hebben we gekeken of de relevantie van deze bestuurlijke thema's in het toezicht gerelateerd is aan de relevantie die binnen de organisatie aan die thema's wordt gegeven. Deze relatie staat in feite centraal in de beleidstheorie van bestuursgericht toezicht. De gedachte is dan dat als de toezichthouder meer nadruk legt op een bepaald bestuurlijk issue - bijvoorbeeld de werking van 
checks-and-balances of financiële continuïteit -, dat dit dan na verloop van tijd ook een steeds belangrijker thema wordt binnen de organisatie. Het externe toezicht beïnvloedt dan de interne bestuurlijke agenda van instellingen. Op die manier zou het bestuursgericht toezicht direct doorwerken in de strategische oriëntatie van instellingen. Analyse laat echter zien dat deze relatie bij onze respondenten, en dus in een kleine populatie, niet te zien is. Er is vrijwel geen correlatie tussen het belang dat aan de thema's wordt gegeven in het toezicht en binnen de organisatie, en er is ook geen relatie tussen de organisatie-interne relevantie van die thema's en de meer algemene ervaring dat er in steeds sterkere mate sprake is van bestuursgericht toezicht. Er is één punt waar bij uitzondering wel een zeer sterke correlatie te zien valt: tussen de focus bij de toezichthouder en de organisatie zelf op de instellingsaudit. Hier loopt de relevantie parallel, maar op de andere punten is (nog?) geen relatie te zien tussen de inhoudelijke focus van de toezichthouder en de interne prioriteiten binnen de organisatie, zoals in de survey gerapporteerd.

\section{Doordachte besluitvorming?}

Een andere manier waarop bestuursgericht toezicht positief zou kunnen doorwerken binnen instellingen is door meer algemeen de kwaliteit van de afwegingen en de besluitvorming te vergroten. Dit correspondeert met een ander perspectief op goed bestuur. Goed bestuur gaat dan niet om het voldoen aan bepaalde normen (zoals een 'fit and proper'-test), het hebben van bepaalde instrumenten (zoals kwaliteitssystemen) en structuren (zoals checks-and-balances), maar schuilt in de kwaliteit van de afwegingen die bestuurders en interne toezichthouders maken in complexe situaties. De gedachte is daarbij dat het van buitenaf onmogelijk is om te beoordelen of besluit A beter of slechter is dan besluit B, maar dat het wel mogelijk is om het besluitvormingsproces als zodanig te analyseren. In de besluitvormingsliteratuur wordt 'cognitieve complexiteit' vaak gebruikt als maat om de kwaliteit van besluitvorming mee te beoordelen (Scott, 1962; Schillemans, 2016). Een cognitief complex besluit wordt gekenmerkt doordat veel informatie wordt verwerkt, geanalyseerd (differentiatie) en vervolgens weer onderling gerelateerd (integratie). De gedachte is dat een hoger geïnformeerd en beter doordacht besluit als zodanig 'beter' is dan een matig geïnformeerd en doordacht besluit, nog los van de eventuele uitkomst of gevolgen. De mate van cognitieve complexiteit van besluiten kan worden onderzocht aan de hand van vragen over informatieverwerking en -afweging (Suedfeld \& Tetlock, 1977; Doney \& Armstrong, 1996; Overman, Schillemans et al 2018).

De analyse laat duidelijk zien dat er een sterk verband zit tussen de antwoorden van onze respondenten rond cognitieve complexiteit en de thema's van bestuursgericht toezicht. Respondenten die in sterkere mate de relevantie van de thema's van bestuursgericht toezicht onderschrijven, geven ook aan meer cognitief complexe besluiten te nemen door meer informatie mee te wegen en beslissingen vanuit meerdere perspectieven te bezien. Er zijn sterke verbanden tussen de meeste 
thema's van bestuursgericht toezicht an sich met hoger geïnformeerde en breder afgewogen besluitvorming.

Deze vorm van mogelijke impact van het bestuursgericht toezicht wordt ook in hun eigen woorden herkend door een deel van onze respondenten. In de open vragen noteren zij dat bestuursgericht toezicht zou kunnen bijdragen aan het vergroten van 'het verantwoordelijkheidsbesef' en de 'bewustwording van onze verantwoordelijkheid en alerter [intern, sic] toezicht'. Het zou de betrokkenen aanzetten zich meer te 'focussen op het belang van de systematische kwaliteitszorg binnen de bestuurlijke organisatie'. Het valt hier niet te zeggen of er sprake is van causaliteit en, zo al het geval, in welke richting. Het zou nader onderzoek vergen om hier preciezer naar te kijken. Het geeft echter wel 'hoop' voor een van de mogelijke manieren waarop bestuursgericht toezicht kan doorwerken, door bestuurders en interne toezichthouders aan te zetten tot meer reflectie en (nog) beter doordachte en geïnformeerde beslissingen.

\section{Gevoelde verantwoording jegens externe toezichthouder?}

Om bestuursgericht toezicht effectief invloed te laten hebben op de governance van publieke organisaties en uiteindelijk, zoals ook de intentie is, op de kwaliteit van dienstverlening, is het nodig dat de rol van de externe toezichthouder in dezen ook binnen de instelling wordt herkend. Ervaren onze respondenten dat zij hierover in een verantwoordingsrelatie tot de toezichthouder staan, en vinden zij dit ook wenselijk en acceptabel? Eerder lieten we zien dat een deel van onze respondenten dit als positief ervaart. Maar er zijn ook respondenten die grote vraagtekens hebben bij de rol van de externe toezichthouder rond het instellingsbestuur. Zo stellen sommigen in de open antwoorden: 'de verantwoordelijkheid (...) ligt op de plek waar die hoort, namelijk bij het bestuur', of 'het bestuur is altijd verantwoordelijk'. Om bestuursgericht toezicht te kunnen laten werken, is het in ieder geval nodig dat de rol van de toezichthouder rond bestuurlijke vraagstukken wordt geaccepteerd.

Om de perceptie van de rol van de externe toezichthouder te onderzoeken hebben we gekeken naar de 'gevoelde verantwoording' ('felt accountability') van de respondenten jegens de externe toezichthouder. Het concept van gevoelde verantwoording is ontleend aan de psychologie (Hall, Frink, \& Buckley, 2015) en is in de vragenlijst vertaald naar de context van de publieke sector (Overman, Grimmelikhuijsen, \& Schillemans, 2018). Gevoelde verantwoording duidt in de kern op de impliciete of expliciete verwachting dat je handelingen of besluiten op een betekenisvolle wijze worden gezien en beoordeeld door een ander (Hochwarter et al., 2007), in dit geval de toezichthouder. Decennia van onderzoek hebben laten zien dat gevoelde verantwoording tal van effecten heeft op besluitvormers, waarvan er vele positief zijn en ook relevant voor het openbaar bestuur. Zo is gevoelde verantwoording positief gerelateerd aan de kwaliteit van besluitvormingsprocessen en wapent zij tegen allerhande gangbare besluitvormingsbiases (Aleksovska, Grimmelikhuijsen, \& Schillemans, 2018). 
Tabel 5 Gevoelde verantwoording jegens externe toezichthouder (schaal 1-7)

\begin{tabular}{lll}
\hline & Gemiddelde & SD \\
\hline Verwachte verantwoording & 4,78 & I,70 \\
Legitieme verantwoording & 5,11 & I,49 \\
Deskundige verantwoording & 4,24 & I,62 \\
\hline
\end{tabular}

Analytisch kan gevoelde verantwoording in drie opeenvolgende aspecten worden onderscheiden. Het gaat in de eerste plaats om de verwachting dat je beslissingen of handelingen zichtbaar (kunnen) zijn voor de toezichthouder die jou beoordeelt. Vervolgens is van belang dat deze gevoelde verantwoordingsrelatie ook als legitiem wordt beoordeeld. En tot slot maakt het uit of de beoordelende toezichthouder ook als deskundig wordt gezien. Onze stelling zou zijn dat als instellingen verwachten dat zij zich over bestuurlijke thema's moeten verantwoorden aan hun toezichthouder, die voorts als gelegitimeerd en deskundig wordt gezien op deze thematiek, dit de kans op een positieve doorwerking van het bestuursgericht toezicht in de besluitvorming en het beleid van instellingen het grootst maakt. Om de gevoelde verantwoording jegens de toezichthouder te identificeren hebben we gebruik gemaakt van de gevalideerde vragenlijst over gevoelde verantwoording (Overman, Grimmelikhuijsen, \& Schillemans, 2018). Tabel 5 beschrijft de gevoelde verantwoording zoals die uit onze vragenlijst naar voren komt.

Bij de verwachte verantwoording jegens de toezichthouder gaat het om de vraag of de respondenten het gevoel hebben dat ze verantwoordelijk worden gehouden door de toezichthouder, en of ze beslissingen moeten uitleggen. Deze gevoelde verantwoording is beperkt en ligt maar een stukje boven de neutrale waarde $(=4)$. Dit beeld is in overeenstemming met de bevindingen over de rapportages richting de toezichthouder, die in aantallen niet heel omvangrijk en frequent zijn. Ook op de directe vraag naar rapportagefrequentie is het antwoord tamelijk laag. Interessant om te zien is dat er sterke correlaties zijn tussen een sterkere bestuursgerichtheid van het toezicht en de gevoelde verantwoording jegens de toezichthouder. Dit is een voor het welslagen van bestuursgericht toezicht opnieuw hoopgevend verband, dat - uiteraard - nog veel meer analyse vergt om precies te kunnen duiden en zeker te kunnen stellen. De legitimiteit van de verantwoordingsrelatie jegens de toezichthouder is vervolgens weer relatief hoog. Los van individuele kritieken en soms sterke uitzonderingen is het overkoepelende beeld hier vrij positief voor de toezichthouders. Legitimiteit is voor toezichthouders een cruciaal 'goed' (zie ook Bokhorst, 2014); dus ook op dit punt zijn deze bevindingen hoopgevend voor de kansen van bestuursgericht toezicht.

De deskundigheid van het toezicht tot slot gaat concreet over vragen ten aanzien van de eenduidigheid van de toezichthouder, het beschikken over voldoende specialistische kennis om te oordelen, het geven van opbouwend commentaar alsook het toepassen van duidelijke criteria in het toezicht. Op dit punt zijn de resultaten van de survey bij deze respondenten het meest bleek en zijn ze dicht bij neu- 
traal. Als de toezichthouder zich in de ervaring van onze respondenten meer richt op bestuurlijke organisatie en governance, dan wordt de expertise relatief hoog ingeschat. Dit suggereert wellicht dat de respondenten menen dat de rol van de toezichthouder inzake bestuur ook primair op dat punt zou moeten liggen. Meer algemeen geeft het mogelijk aan dat de perceptie dat de toezichthouder deskundig over bestuur kan oordelen, nog moet worden 'veroverd' of 'verdiend' door de externe toezichthouders. De inhoudelijke invulling zou momenteel volgens de nodige respondenten nog 'erg zoeken' zijn of voorbijgaan aan wat de 'bedoeling' van het werk van de instelling is.

\section{Bestuurlijke stijlverschillen}

Tot besluit laat het onderzoek op twee punten belangrijke stijlverschillen zien tussen onze respondenten die relevant zijn in relatie tot bestuursgericht toezicht. In de eerste plaats is er een duidelijk verschil tussen respondenten met een sterke focus op informele relaties en contacten en respondenten met een sterke focus juist op formele relaties en contacten. Dit type onderscheid is in wat andere termen al eerder gevonden in onderzoek naar toezicht en verantwoording (Lupson \& Partington, 2011; Schillemans, 2015). Dit is relevant voor bestuursgericht toezicht, omdat respondenten hierin een sterk verschillende bestuursstijl laten zien. Sommige bestuurders koersen sterk op formele relaties en formele rollen en bevoegdheden, terwijl andere veel sterker koersen op informele relaties, contacten en wijzen van beïnvloeden. Wil bestuursgericht toezicht kunnen aansluiten bij het bestuur van instellingen, dan zou het ook recht moeten kunnen doen aan dit type stijlverschillen tussen bestuurders, wat hoge eisen stelt aan het externe toezicht.

In het verlengde daarvan en in de tweede plaats zitten er in het onderzoek tal van correlaties tussen aspecten van bestuursgericht toezicht en de stakeholderoriëntatie van de respondenten. Respondenten die op veel thema's bestuursgericht toezicht herkennen, onderschrijven in sterke mate ook het belang van stakeholdermanagement op allerlei niveaus. Er is een vraag over het belang van relaties met stakeholders op strategisch niveau die zeer sterk samenhangt met veel aspecten van bestuursgericht toezicht. Vragen over strategisch contact met stakeholders correleren ook sterk met forumexpertise en forumlegitimiteit. Dit suggereert dat er een soort van Wahlverwantschaft is tussen bestuursgericht toezicht en een actieve en positieve stakeholderoriëntatie van bestuurders bij instellingen. Dit verband zou nader kunnen worden onderzocht, omdat het wellicht kansen biedt om bestuursgericht toezicht beter te begrijpen.

\section{Conclusie}

Dit artikel wilde inzicht bieden in de resultaten en eerste analyses van een beperkte survey naar de ervaringen met bestuursgericht toezicht bij vooral interne toezichthouders in onderwijs, zorg en wonen, als empirische basis voor dit themanummer. De resultaten suggereren dat het bestuursgericht toezicht zich 
momenteel vooral focust op de systemen van kwaliteitszorg binnen instellingen. Ook suggereren de resultaten dat de eerste ervaringen en resultaten nog heel wisselend zijn. Dat is niet verrassend voor een nog jonge praktijk. Het artikel suggereert dat bestuursgericht toezicht een ontluikende praktijk is die nog heel wisselend wordt waargenomen door onze respondenten. Het is daarmee een nieuwe en qua impact ogenschijnlijk nog bescheiden praktijk, die door betrokken instellingen heel wisselend wordt beoordeeld, zowel feitelijk als normatief. Respondenten variëren in sterke bevestiging en ontkenning van de wending naar bestuursgericht toezicht en van een heel positieve tot een heel kritische beoordeling van praktijken. Daaruit komt een wat bleek gemiddeld oppervlaktebeeld van de praktijk van bestuursgericht toezicht naar voren, waarachter echter sterk wisselende ervaringen en beoordelingen van onze respondenten schuilgaan.

Directe relaties tussen het bestuursgericht toezicht en strategische bestuurlijke prioriteiten van de respondenten komen in dit bescheiden onderzoek niet naar voren. Wel is zichtbaar dat de inhoudelijk bestuurlijke thema's gemiddeld genomen van belang worden gevonden bij de instellingen. Ook zou er een agenderend en bewustwordend effect kunnen zijn van bestuursgericht toezicht. Voorts zit er in deze data een duidelijk verband tussen beter doordacht en geïnformeerd bestuurlijk beslissen met thema's van bestuursgericht toezicht, wat op een andere vorm van doorwerking zou kunnen duiden. De rol van de externe toezichthouder wordt als behoorlijk legitiem ervaren, hetgeen in ieder geval 'kansen' biedt voor bestuursgericht toezicht. De ervaren expertise van de toezichthouder lijkt op grond van deze data het voornaamste ontwikkelpunt.

Onze zeer voorlopige conclusies zijn vervat in de titel van dit artikel: 'voorlopige contouren'. Die titel staat voor vier betekenissen. We spreken om te beginnen van voorlopige contouren omdat we rapporteren op grond van heel bescheiden onderzoek met een bescheiden respons en we dus heel terughoudend moeten zijn in hoe we de resultaten interpreteren. Het zijn verder ook voorlopige contouren omdat het nog vroeg dag is voor de analyse van een jonge praktijk; het bestuursgericht toezicht heeft nog weinig tijd gehad om vorm te krijgen, zich te vestigen en zich te ontwikkelen. In de derde plaats is de metafoor ook feitelijk bedoeld: voor onze respondenten is niet eenduidig helder in welke mate bestuursgericht toezicht in de praktijk al van de grond is gekomen. De ervaringen en beoordelingen die in ons bescheiden onderzoek naar voren komen, zijn heel wisselend en schetsen tegenstrijdige beelden. In de vierde plaats verwijzen de voorlopige contouren ook naar de inhoudelijke focus. Voor onze respondenten is niet eenduidig helder wat bestuursgericht toezicht inhoudelijk is en vooral ook zou moeten zijn. Dat vraagt nog om veel nadere reflectie en debat. Dit artikel met voorlopige contouren, en vooral het gehele themanummer als zodanig, draagt daar hopelijk aan bij. Deze survey zou in de verdere ontwikkeling van het bestuursgericht toezicht kunnen dienen als een nulmeting, die over een aantal jaren kan worden herhaald, en dan als contrast kan dienen om de ontwikkeling naar meer gevestigde contouren van bestuursgericht toezicht met meer precisie te kunnen schetsen en duiden. 


\section{Literatuur}

Aleksovska, M., Grimmelikhuijsen, S., \& Schillemans, T. (2018). Systematic review of experimental accountability studies. Congres paper ECPR Joint Sessions.

Autoriteit woningcorporaties. (2018). Governance.https://www.ilent.nl/onderwerpen/ toezicht-autoriteit-woningcorporaties/governance

Ayres, I., \& Braithwaite, J. (1995). Responsive regulation: Transcending the deregulation debate. New York: Oxford University Press.

Bokhorst, A.M. (2014). Bronnen van legitimiteit. Over de zoektocht van de wetgever naar zeggenschap en gezag. Den Haag: Boom Juridische uitgevers.

Bovens, M., \& Schillemans, T. (2009). Handboek publieke verantwoording. Den Haag: Lemma.

Doney, P.M., \& Armstrong, G.M. (1996). Effects of accountability on symbolic information search and information analysis by organizational buyers. Journal of the Academy of Marketing Science, 24(1), 57-65.

Hall, A.T., Frink, D.D., \& Buckley, M.R. (2015). An accountability account: A review and synthesis of the theoretical and empirical research on felt accountability. Journal of Organizational Behavior, 38(2), 204-224.

Hochwarter, W.A., Ferris, G.R., Gavin, M.B., Perrewé, P.L., Hall, A.T., \& Frink, D.D. (2007). Political skill as neutralizer of felt accountability - job tension effects on job performance ratings: A longitudinal investigation. Organizational Behavior and Human Decision Processes, 102(2), 226-239.

Hood, C., James, O., Scott, C., Jones, G.W., \& Travers, T. (1999). Regulation inside government: Waste watchers, quality police, and sleaze-busters. Oxford: Oxford University Press.

Inspectie Gezondheidszorg en Jeugd. (2016). Toezicht op goed bestuur.https://www.igj.nl/ documenten/publicaties/2016/07/06/kader-toezicht-op-goed-bestuur

Inspectie van het Onderwijs. (2016). Vernieuwd toezicht. https://www.onderwijsinspectie. nl/binaries/onderwijsinspectie/documenten/publicaties/2016/11/24/presentatievernieuwd-toezicht-regiobijeenkomst-vo-21-11/Presentatie+regiobijeenkomst $+21+$ november+2016+vernieuwd+toezicht+voortgezet+onderwijs.pdf

Lupson, J., \& Partington, D. (2011). Individual civil servants' conceptions of accountability: A preliminary study. Public Management Review, 13(7), 895-918.

Overman, S., Schillemans, T. et al. (2018). Comparing governance, agencies and accountability in seven countries. CPA Survey Report. Utrecht University School of Governance. https://accountablegovernance.sites.uu.nl/wp-content/uploads/sites/131/2018/03/ 2018-Survey-report-Governance-Accountability-Agencies.pdf

Overman, S., Grimmelikhuijsen, S., \& Schillemans, T. (2018). Measuring felt accountability: Expectation, legitimacy and expertise. Congres paper EGPA 2018.

Schillemans, T. (2015). Managing public accountability: How public managers manage public accountability. International Journal of Public Administration, 38(6), 433-441.

Schillemans, T. (2016). Calibrating public sector accountability: Translating experimental findings to public sector accountability. Public Management Review, 18(9), 1400-1420.

Scott, W.A. (1962). Cognitive complexity and cognitive flexibility. Sociometry , 405-414.

Suedfeld, P., \& Tetlock, P. (1977). Integrative complexity of communications in international crises. Journal of Conflict Resolution, 21(1), 169-184. 